DOI: https://dx.doi.org/10.24093/awej/vol12no4.3

\title{
Online Literature Circles in Learning Hamlet among Pre-service Teachers
}

\author{
Tina Abdullah \\ Language Academy \\ Faculty of Social Sciences and Humanities \\ Universiti Teknologi Malaysia, Malaysia \\ Corresponding Author: tinaabdullah@utm.my \\ Yee Bee Choo \\ English Language Department \\ Institute of Teacher Education Tun Hussein Onn Campus, Malaysia \\ Norhanim Abdul Samat \\ Language Academy \\ Faculty of Social Sciences and Humanities \\ Universiti Teknologi Malaysia, Malaysia
}

Received: 7/6/2021

Accepted: 9/30/2021

Published:12/15/2021

\section{Abstract}

Literature instruction may serve multiple functions. This case study aimed at investigating the perceptions on the use of online literature circles among 62 first year Teaching English as a Second Language pre-service teachers in a literature course at Universiti Teknologi Malaysia. The participants were assigned to read and participate in online literature circles about the play Hamlet by William Shakespeare. Based on cooperative learning, the participants rotated in playing the roles of the Discussion Director, Device Detective, Imaginative Illustrator, Creative Connector, and Passage Picker in each group. Data from a survey were analyzed in descriptive statistics, while data from the role sheets based on the five roles and the online video of 3 literature circle discussions were analyzed thematically. The findings are significant for teacher training institutions and in-service teachers. This study was able to show that online literature circles were perceived as interesting, engaging, challenging, and fun. The participants engaged in different learning processes involving cognitive, affective, and language skills. Though this study identified some challenges, online literature circles have many benefits and are recommended for literature instruction for pre-service teacher training.

Keywords: Online literature circle, pre-service teacher training, roles in literature circles, Shakespeare's Hamlet

Cite as: Abdullah, T., Yee, B. C., \& Abdul Samat, N. (2021). Online Literature Circles in Learning Hamlet among Pre-service Teachers. Arab World English Journal, 12 (4) 37- 52. DOI: https://dx.doi.org/10.24093/awej/vol12no4. 


\section{Introduction}

Literature has become part of many curricula in different countries. In Malaysia, it has been in the education system to address different purposes and learning outcomes across different levels. In primary school, it is taught as Language Arts and young learners are encouraged to appreciate and demonstrate understanding of English literature. They also learn to do creative works for enjoyment through chants, rhymes, action songs, songs, poems, stories, and graphic novels. At the secondary level, literature is incorporated to nurture skills in responding, analyzing and evaluating a variety of literary genres in English from poetry, graphic novels, short stories, novels, and plays. At the higher education, literature is often offered as a core or elective course to develop and advance content knowledge and thinking skills apart from refining competency in the English language.

While literature has numerous functions in the education system, instructional evolution and developments in Information and Communication Technology have revolutionized its versatility and transformed the way classrooms embrace its teaching and learning. At the tertiary level, literature instruction that prepares pre-service teachers for the Teaching of English as a Second Language (TESL) can serve multiple functions like to instil the passion for reading, build aesthetic appreciation through language, foster higher-order thinking abilities, or nurture personal growth (Greef, Jenkins \& Comer, 2021). To provide support for these learners, literature instruction offers not just a platform for exploring and experimenting with different literary genres for the teaching of the English language, but also exposes them to the pedagogical processes that nurture agility and resilience that are vital for developing professional attributes to become future educators (Masry \& Alzaanin, 2021). Hence, literature instruction is important to nurture knowledge and different skills (Alamoudi, 2021) involving language, cognitive, affective as well as attributes concerning social, ethics, and passion towards the teaching profession. The strong training ground prepares TESL pre-service teachers to adapt to changes and developments (Nor Pazilah, Hashim \& Md Yunus, 2021) to become future teachers.

Although much effort to guarantee the relevance and worth of literature instruction for the training of TESL pre-service teachers has been established, there are bound to be issues that may affect its novel purpose or instructional process. Fundamental issues in reading like engagement, motivation, and confidence may impede or influence the learning outcomes. In the instructional process, issues in monitoring individual improvement or participation may also be potential challenges. Meanwhile, technological advancement and specific events like the Covid-19 pandemic outbreak have inevitably affected the mode of training and delivery (Li, 2018; Dhawan, 2020). The conventional face-to-face classroom practice has moved to the online or face-to-screen platforms (Moorhouse, 2020). The adjustment has instigated other possible challenges. Therefore, it is vital to obtain insights into learners' perceptions of their experience through the changes in the learning process to advance the recent educational practice and to enlighten current discussions about classroom practices (Bloemert, Paran, Jansen \& Grift, 2019) in literature instruction among TESL pre-service teachers. This case study uncovers the perceptions of TESL pre-service teachers on the use of online literature circles for the learning of a Shakespeare's play, Hamlet. The findings are beneficial for teacher training institutions and inservice teachers. The research questions are:

1. What are the learners' perceptions of using online literature circles in learning a Shakespeare's play? 
2. What are the challenges faced by the learners in learning a Shakespeare's play through online literature circles?

3. How do the learners overcome the challenges faced in learning a Shakespeare's play through online literature circles?

\section{Literature Review}

This section discusses general challenges in literature instruction before highlighting literature instruction for teacher training. The section proceeds with discussing the literature circles model based on cooperative learning as the framework for this article (Daniels, 2002).

Classroom practice and research discovered diverse challenges in literature instruction. A common challenge is the conventional teacher-centered approach that gives freedom for instructors to orchestrate instructional process through chalk and talk. Known as the Initiation, Response, and Evaluation (IRE) discourse structure, it supports instructors' role in modeling the prescribed meaning in literature while giving an opportunity for learners to participate in answering questions about literature (Beach \& O'Brien, 2017). It also allows instructors to check if learners read and understand the assigned text. Nurhadi (2017) explained that IRE supports reading comprehension as learners get to respond orally to questions in class discussions which, according to Joni (2019), promotes active participation in the classroom. Nevertheless, it is also criticized for its limitations. While IRE wastes classroom discussion efforts (Alexander, 2018), it also limits personal engagement, aesthetic pleasure, and higher-order thinking processes among learners as meaning makers (Karolides, 2020). This may result in the loss of interest and appreciation for reading literature or restrict exploration into generative thinking processes (Rosenblatt, 1978), which are crucial to safeguard the significance or versatility of literature in any classroom, course, or program of study.

Proponents of student-centered literature instruction like Daniels (2002) and Rosenblatt (1978) recommended allowing learners to explore personal meaning in literary texts, not just the meaning prescribed by instructors. This makes learning meaningful and serves multiple functions for cognitive, affective, and language advancements (Karolides, 2020). Focusing on cognitive advancement, learners get to explore meaning in literature from multiple perspectives involving critical, creative, and imaginative thinking (Noah, 2018). When personal meaning is central, literature enhances affective developments through personal connections and responses in the meaning-making process (Rosenblatt, 1978). In the case of language development by studying the works of Shakespeare, learners may be challenged to understand unknown and unfamiliar language such as words that have shifted in meaning, different syntax order, complex metaphor, and unfamiliar cultural knowledge (Murphy, Culpeper \& Gillings, 2020). However, studentcentered instruction encourages exploration of personal meaning, which promotes independence and ownership in learning among learners (Ardi, 2017; Dogan, Yildirim, Cermik \& Ates, 2020).

An established student-centered model for literature instruction, that has drawn much attention in research and classroom practice, is literature circles. Described as "small, peer-led discussion groups whose members have chosen to read the same story, poem, article, or book" (Daniels, 2002, p.2), it promotes the concept of cooperative learning. Literature circles conducted by assigning roles to every member in a group, require learners to read and discuss literary texts according to the roles. The students can play different roles: questioner, connector, 
literary luminary, and illustrator (Daniels, 2002). The groups rotate the roles each time they get into a literature circle, and everyone functions as the 'expert' and is responsible for guiding the discussion based on the assigned role (Çetinkaya \& Topçam, 2019; Dogan et al., 2020). According to Li, Chen, Su and Yue (2021, p. 919), "these individual roles provide students with a clear reason for reading ...The fulfilment of each role is often considered as a major contributor to the success of literature circles." While the roles support in-depth reading and discussion about literature (Çetinkaya \& Topçam, 2019), Bales (2021, p. 18) explained that they "encourage readers to interpret texts in different ways and, in combination, lead to a multiple interpretation of a text through the application of a range of cognitive learning styles."

While cooperative learning is highly effective in making learners learn through group work (Vygotsky, 1978), literature circles show positive effects of interdependence in group work, and the importance of personal responsibility through the roles (Çetinkaya \& Topçam, 2019; Novitasari, Rahayu \& Suryanto, 2021). In literature circles, each group member has to take charge of a specific aspect of literature and helps the group to observe meaning from the perspective presented through the assigned role. Each member encourages one another to contribute and respond to ideas in the discussion.

Literature circles encourage personal involvement as they nurture autonomy among learners as meaning makers. According to Rosenblatt (1978), learners can take either the "efferent" or "aesthetic" stance in meaning-making. Most classrooms that adopt the IRE discourse structure focus on developing the efferent stance that requires learners to gather and retain information obtained in literature (Sefhedi, Omidire, Ebersöhn, \& Murphy, 2020). When this happens, literature instruction is about building structured knowledge. Learners should be given the freedom to adopt the aesthetic stance in literature instruction during meaning-making. It involves engagement of personal feelings, ideas, and attitudes about literature and life (Karolides, 2020). Literature circles offer an avenue to explore both efferent and aesthetic experiences in literature instruction ( $\mathrm{Li}, 2018)$.

When learners are free to explore personal meaning through different stances in literature circles, it leads to greater motivation in reading and exploring personal sense of experience with literature (Karolides, 2020). When freedom is given to navigate group discussion, learners are empowered to manage their learning (Ardi, 2017), which motivates them to develop favorable attitudes toward literature $(\mathrm{Li}, 2018)$. Literature circles create opportunities for learners to engage in meaningful productive discussions that promote intrinsic motivation important for developing reading habits, interests, and positive attitudes towards literature (Dogan et al., 2020).

Moreover, literature circles encompass literacy strategies and skills that promote reflective practices from personal to critical through interaction with others. Reflecting on social experiences according to Masry and Alzaanin (2021, p. 438) should "help inform identity construction positively." They share responsibility for managing the group discussions by asking, responding, and making judgments through reflection and reasoning (Daniels, 2002). This type of thinking is deep and supports the exploration of higher-order thinking in becoming independent meaning makers. This differs from the IRE literature instruction, where learners are passive receivers of knowledge with little opportunity to explore personal connection, response, or critical reflections about personal experience with literature (Rosenblatt, 1978). 
According to Vygotsky (1978), social interaction is central for learning as it reinforces and advances different skills and attributes like teamwork, higher-order thinking skills, and language proficiency. Literature circles prepare learners to work in teams to question, reflect, and learn from one another (Noah, 2018). In groups, learners share control over the key aspects of meaning in literature and become active meaning makers through social interactions about literature (Daniels, 2002). The experience gained from building meaning together serves multiple functions and encourages cooperation.

While serving multiple functions for overall educational development, as a student-centered model, its position in pre-service teacher training is just as important. Precisely, incorporating literature circles in TESL pre-service teachers' programs prepare trainees to effectively use literature to teach and become the platform for the development of holistic future-ready educators (Kaşlıoğlu \& Ersin, 2018). Current developments in research on literature circles for pre-service teachers show interesting discoveries.

In a study documented by Dogan et al. (2020), pre-service teachers were found to be engaged as meaning makers when they read and shared their experience in literature circles. The participants were curious and enthusiastic about sharing their thoughts and views in the discussions. Aytan (2018) also found that pre-service teachers perceived literature circles as favorable as they encourage cooperation, solidarity, development of different perspectives, exposure of hidden talents, self-confidence, aesthetic pleasure, vocabulary building, and identification of details in literature.

The fast development in technology and the unprecedented spread of the Covid-19 pandemic, have changed the traditional face-to-face literature circles to follow the new trend in the online mode. In the case of online literature circles, Imamyartha et al. (2021, p. 295) described it as "an apt avenue for teachers to enhance their practices to prepare students for a technological society." According to Cave (2018), online literature circles are a great way to hold learners accountable for assigned readings. The platform has also developed critical thinking, collaboration, personal connections, differentiation, exposure to different genres, and positive feedback (Cave, 2018). Li (2018) and Combes (2021) also discussed its major benefits in providing more time to think, equal discussion, unconfined space and time, more writing opportunities, and automatic records.

A study conducted by Varga, McGuinn, Naylor, Rimmereide, and Syed (2020) on university learners from Norway, Pakistan and the United Kingdom found that online literature circles stimulated conversations not only with those within the national context but were successful in providing the opportunity for discussions with learners from other contexts. However, they cautioned that instructors need to tailor the roles in literature circles. This is vital to ensure that specific, clear instructions and responsibilities are spelled out for the different roles. The running of the literature circles would safeguard the success and quality in the learning and training of pre-service teachers that transpire through the online literature circle discussions.

Although much research has documented the benefits of implementing literature circles, the adoption of online literature circles among pre-service teachers has yet to receive much attention (Ferdiansyah, Ridho, Sembilan, \& Zahro, 2020) and needs further investigation. Research into it 
would build confidence and increase chances for the use of literature circles in future classroom practice (Fortune, Horst, Kessler, Tackett \& Pennington, 2021). This study supports specifically the development in research investigating the use of online literature circles for the training of TESL pre-service teachers in exploring Hamlet, a Shakespeare's play.

\section{Methods}

The study was a mixed-method case study. It was chosen to provide an in-depth understanding of the pre-service teachers' perceptions of online literature circles. It was conducted at Universiti Teknologi Malaysia.

\section{Participants}

The participants were selected based on purposive sampling among a population of 62 firstyear TESL pre-service teachers. The participants were a homogenous group with similar age, language, education, and cultural background. They enrolled for an introductory literature course that was conducted online during the Covid-19 outbreak. They attended the online classes from September 2020 to January 2021 from their hometown.

\section{Research Instruments}

The data collection method was quantitative through a survey conducted using Google Form. It was distributed to the participants to find out about their perceptions of online literature circles. The qualitative data in the form of specific role sheets were designed and used for the five roles in the online literature circles and the recording of the online literature circle discussion sessions. The five role sheets were assigned specific names and tasks as presented in Table one.

Table 1. Name and description of the roles used in the online literature circles

\begin{tabular}{lll}
\multicolumn{1}{c}{ Roles } & & \multicolumn{1}{c}{ Description } \\
\hline Clever Connector & $:$ & $\begin{array}{l}\text { Find a connection between the text and the world outside. Describe the } \\
\text { kind of connection: Text to Self, Text to Text, or Text to World. } \\
\text { Develop a discussion topic / issue / question. It might be about a specific } \\
\text { situation, theme, or character in the text. }\end{array}$ \\
Passage Picker & $:$ & $\begin{array}{l}\text { Choose a section from the text. Describe and state the reason(s) for } \\
\text { choosing it. }\end{array}$ \\
Device Detective & $:$ & $\begin{array}{l}\text { Identify a literary device. Describe what and where the device is in the } \\
\text { text. Explain the use of the device and state the reason(s) for choosing it. }\end{array}$ \\
Imaginative Illustrator & $:$ & $\begin{array}{l}\text { Select a section from the text that can be visualized/imagined. Illustrate / } \\
\text { draw a sketch, cartoon, diagram, or any kind of graphic organizer. }\end{array}$ \\
\hline
\end{tabular}

\section{Research Procedures}

The participants were assigned to read different literary genres that began with short stories and poetry, then to plays. Online literature circles were conducted throughout four months within a semester. For this study, the analysis was conducted on the five online literature circle sessions based on the play Hamlet by William Shakespeare. The play was introduced after the participants were exposed and given enough training for online literature circles. Also, it would be valuable to investigate the participants' perception of online literature circles based on a canonical text. 
As the play has a total of five acts, each session focused on one act and took place consecutively over five weeks. The participants rotated the five different roles in the literature circles in each group for the five acts in the play. Every participant had the opportunity to experience the five different roles throughout the literature circle sessions for the five acts in the play. They had to complete the role sheet that was specifically designed to guide them in reading and preparing for the online literature circle discussion sessions.

Before the implementation of the online literature circles, the students were briefed on the use of the five roles with the accompanying role sheets, and the structure of the online literature circle discussion sessions. All the materials prepared for the literature circles including the literary texts, notes, and links to instructional videos or secondary resources were shared through the e-learning platform. The participants joined the literature circle discussion sessions through the Learning Management System (LMS) used by the university. They recorded their online literature circle discussion sessions and shared the videos with the class through Telegram. They also shared their role sheets through Padlet. This was done specifically for the purpose to share and extend the participants' learning experience in exploring meaning. At the end of the fifth session, a survey was administered through Google Form to reach out to all 62 participants.

The quantitative data from the survey on TESL pre-service teachers' perceptions of online literature circles were generated automatically and tabulated descriptively in percentage form through Microsoft Excel. The qualitative data from the role sheets and the online literature circle discussion sessions were analyzed thematically according to the research questions.

\section{Results}

Based on the first research question, which aimed to discover the general perceptions of the learners on reading and participating in online literature circles about Hamlet, a Shakespeare's play, the following are two figures showing the overall results. Figure one shows their overall perceptions of online literature circles, while Figure two depicts their perceptions of the specific roles in the online literature circles.

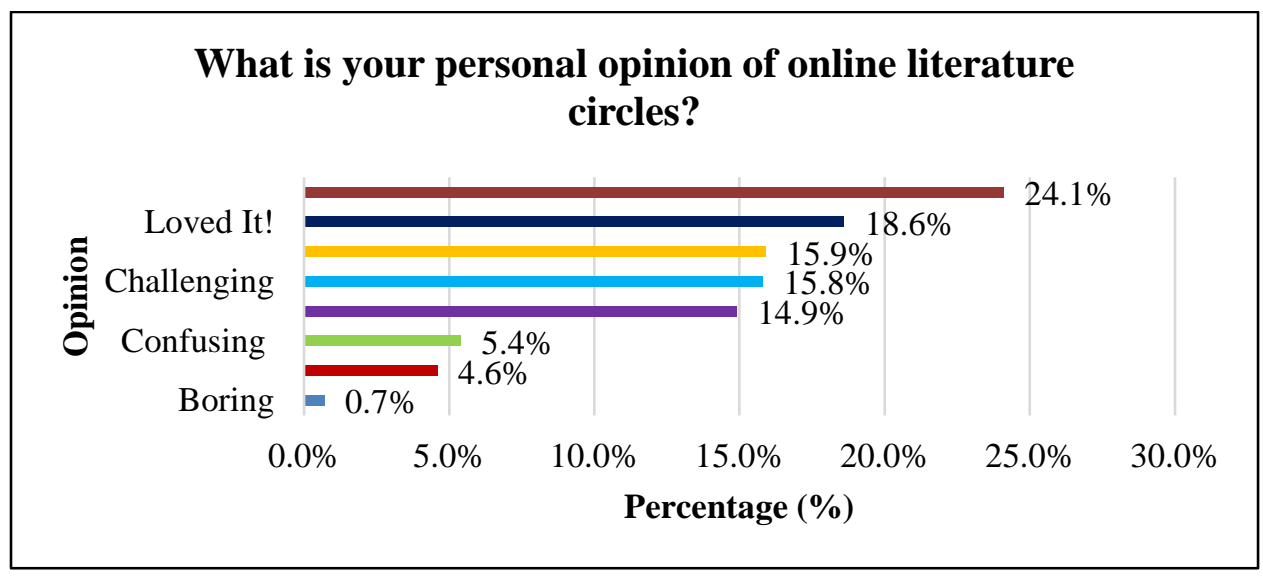

Figure 1. Overall perceptions on online literature circles

Figure one indicates that the online literature circles were perceived positively among the participants. The majority said that the online literature circles were interesting (24.1\%), and they 
loved it (18.6\%). Others regarded online literature circles as engaging (15.9\%), fun (14.9\%), and easy $(5.6 \%)$. However, some participants perceived them as challenging $(15.8 \%)$, and a few felt they were confusing $(5.4 \%)$ and boring $(0.7 \%)$.

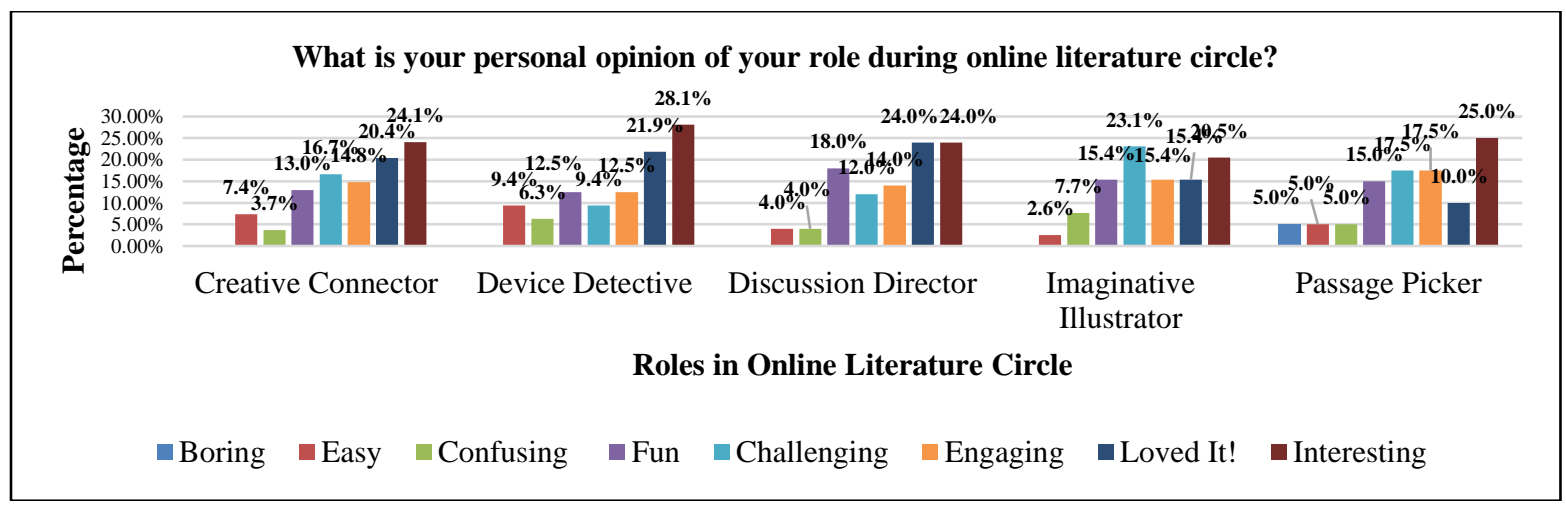

Figure 2. Learners' perceptions of the specific roles in the online literature circles

Figure two reveals that majority of the participants had positive perceptions about all five roles. Generally, all five roles were perceived as interesting as it was the highest response. This shows that the participants were engaged in learning through the online literature circles.

In examining the findings of the specific roles for the online literature circles in Figure two, the participants showed positive perceptions of the Creative Connector's role. Although more (16.7\%) participants found the role to be challenging as opposed to easy (7.4\%), many accredited it as interesting $(24.1 \%)$, and they loved it $(20.4 \%)$. The following were testimonies given about the role in the survey.

"It really touched my heart, especially when Ophelia drowned herself after her father's death."

"It was a bit emotional when we went through the connection, yet still fun because everyone was responsive."

Of the five roles in the online literature circles, the role of the Device Detective was nominated as the most interesting role $(28.1 \%)$ and easiest $(9.4 \%)$. During the literature circle discussion, the Device Detective from Group four found two literary devices in Act one that are 'imagery' and 'personification.' The following is an excerpt from their online literature circle discussion about the literary devices.

Table 2. Online Literature Circle discussion on Literary Devices

Isya: When Horatio said "This bodes some strange eruption to our state" in Scene 1, Line 68, this shows imagery was used by Shakespeare to picture how the presence of the ghost has affected the state. There are many types of imagery, such as visual imagery, thermal imagery, auditory imagery. In this case, visual imagery is used to describe the effects of the ghost on the state.

Sara: What is thermal imagery?

Isya: Thermal imagery is something related to temperature. It is to show or emphasize the condition of something but with temperature, for example, the warm ocean water. "Warm" is an example of thermal imagery to show 
the temperature of the water.

Ok, now let me share about personification. Horatio said, "But look, the morn, in russet mantle clad, walks o'er the dew of yon high eastward hill" in Scene 1, Lines 165-166. Horatio was describing morning as a person as it was wearing reddish brown clothing and did the action of walking.

Reen: When reading the play, most of the time, I spotted many personifications. However, the examples given during our discussion were not the same as what I have found, so it makes me understand more about personification as one of the amazing ways to describe a person or a thing.

Rose: I love the use of personification in Hamlet that you explained, which is the personification of morning. I think that it was a creative way to describe the action of the morning, and I think it helps the reader use their thinking skills a bit in getting the meaning of that particular part.

Anas: I also noticed the use of personification when reading Hamlet and the examples you gave are the same as what I have found. I was not clear about certain words, but after listening to your explanation, I know what they mean.

As for the role of the Discussion Director, many participants loved it (24.0\%) and found it fun (18.0\%). They had a great time to lead their members in the discussion and listen to ideas, opinions, and perspectives. Their comments in the survey about the role were such as "It was great!", "I had a great time", and "It was fun and informative" show that the participants had positive perceptions about it. Some loved the role as one participant in the survey said,

"The discussion was indeed rich with ideas and perspectives. I wish the lecturer could listen to our discussion."

Another participant felt it was so fun as he stated,

"We keep giving a lot of ideas and opinions regarding the act."

Among the roles, the Imaginative Illustrator was identified as the most challenging (23.1\%) and confusing (7.7\%). Some thought the role was fun $(15.4 \%)$, engaging (15.4\%), or they loved it $(15.4 \%)$. The following are the illustration and description given about Ophelia in Act four, Scene five by the Imaginative Illustrator from Group six in her role sheet.

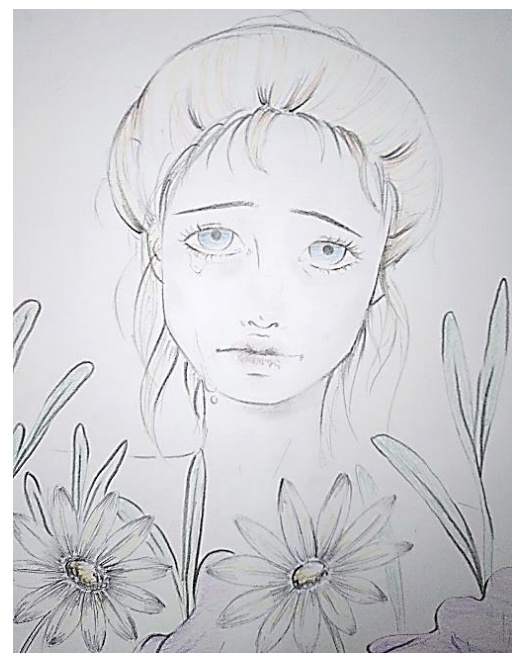

Figure 3. Illustration by an Imaginative Illustrator in the online literature circles 
The illustration is a portrait of Ophelia, with unkempt hair, sunken cheeks and eyes, and rosemary and daisy flowers around her, singing the song while a tear rolls down her right cheek. According to Ophelia, the rosemary is for remembering. The daisy means unhappy love. I tried to capture Ophelia's crazed self, after the death of her father, and her lover leaving her. I drew this portrait because I empathized with her fragile and young self. I felt that in her insanity, she was just a broken girl that did not deserve the tragedy.

In presenting this illustration in the online literature circle discussion, one of the members in the group mentioned the following:

I want to talk about how I'm feeling based on this drawing. Some people will feel bad for Hamlet during the whole story, but I feel bad for Ophelia. I think that her story is very tragic compared to Hamlet's. I can relate the drawing to the theme - reality and deception, and truth and madness. Also, the flowers that Ophelia was holding.

Based on Figure two, the role of the Passage Picker was voted as the second most interesting (25.0\%) and engaging (17.5\%). In an online literature circle, a Passage Picker from Group nine selected Line 56 from Act Three Scene Three, where King Claudius said, "May one be pardon'd and retain th' offence?" The following was his reason for choosing it:

I think it's interesting that Claudius is consumed with guilt. Before this, he mentioned briefly (Act three Scene one, Line 50-55) that he felt guilty but only started praying about his sins until Scene three. I think this scene shows the ugliness of humanity. Because we all at some point have committed a sin that resulted in us reaping the benefits of it, and even though we feel guilty about it, we still reap the fruits of it.

In response to the reason given in the online literature circle discussion for choosing the line, one member from Group nine gave the following comment:

I think this passage is good. It shows that even a killer has a bit of humanity left in him. It shows that every person is good and bad, depending on the situation. Inside us, everyone will have a negative and positive personality. When Claudius prays, he shows regret for his actions. From my point of view, even though Claudius did something good in his eyes, the effects of that doing will be bad in the eyes of others.

Based on the second research question, the following demonstrates the findings on the challenges faced by the participants in learning Hamlet through online literature circles. Below are the responses given by the participants in the survey conducted. Table 3. Challenges faced by the participants during the online literature circle

\begin{tabular}{llcc}
\hline \multicolumn{1}{c}{ Challenges } & Number of participants & Percentage \\
& & $(\mathrm{N})$ & 62.9 \\
\hline 1 & No problem & 39 & 11.3 \\
2 & Difficulty in understanding Shakespeare's text & 7 & 11.3 \\
3 & Challenges with the roles & 7 & 9.7 \\
4 & Internet connection & 6 & 3.2 \\
5 & Time management & 2 & 1.6 \\
6 & Lack of technological skills & 1 & 100 \\
\hline \multicolumn{1}{r}{ TOTAL } & 62 & \\
\hline
\end{tabular}


Table three demonstrates that majority of the participants did not have any problem $(62.9 \%)$ in the online literature circles. However, there were a few challenges that some participants experienced. The two main challenges were related to difficulty in understanding Shakespeare's language $(11.3 \%)$ and the roles $(11.3 \%)$ they played during the online literature circles. The following were their responses about the challenges in Shakespeare's language obtained in the survey.

"I think trying to understand the Old English words is quite hard. Because I googled the words that I don't know, and there are a lot."

"The language used in Hamlet sometimes is a bit confusing for me, but I managed to understand after reading it several times."

These were the responses given about the challenges with the roles in the online literature circles.

"I am bad at drawing and struggling with creativity." (The Imaginative Illustrator)

"It's quite hard for me to make the connection. But, at last, I manage to complete my task after doing a lot of reading." (The Clever Connector)

A few participants $(9.7 \%)$ faced problems with internet connection when low internet bandwidth and weather conditions caused interruptions. Finally, less than a handful admitted to having time management $(3.2 \%)$ or technology skills (1.6\%) as challenges.

The participants' perception of the challenges in the online literature circles inevitably steered other discoveries. Based on the third research question, the following were comments given by the participants about how they overcame the challenges they faced in learning Hamlet through the online literature circles. Some relied on the members of the group as revealed below.

There were things we don't know. But my groupmate who watched the movie explained to us very well.

Since the play is quite long and the language is hard to understand, I received some input from my friends.

Two participants perceived that the storyline was easier to understand when they discussed their connections. Others attempted to explore privately, as mentioned below,

"I find it very difficult to relate the play to my real experience, so I just connect it to a drama I recently watched."

Though learning technological skills need time and effort, the participants voluntarily explored different applications to address their weaknesses. This was especially true for the role of the Imaginative Illustrator, who is responsible for drawing or sketching images that represent their imagination. Some tried to use technology to develop their illustrations. The following 
picture done by the Imaginative Illustrator from Group five shows how he visualized the last act of Hamlet when everyone died at the end of the scene except for Horatio, who later lived to tell the actual tragedy.

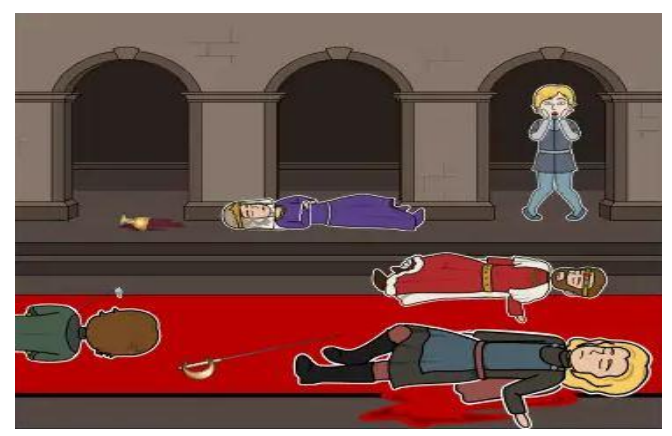

Figure 4. An illustration created by an Imaginative Illustrator using Canva

\section{Discussion}

Based on research question one, this study demonstrated that the participants had positive perceptions of the online literature circles as majority perceived it as interesting, engaging and they loved it. This finding concurs with studies by Ferdiansyah et al. (2020), Fortune et al. (2021), and Novitasari et al. (2021). The online literature circles successfully provided encouraging and enjoyable learning experiences for learners which develop motivation and positive attitudes towards literature (Dogan et al., 2020).

A close look at the perceptions of the roles showed very positive discoveries. For instance, the role of the Device Detective that was perceived as the most interesting role, provided the opportunity for the participants to become independent learners when they discussed literary devices based on multiple perspectives. This finding corresponds with studies by Cave (2018) and Imamyartha et al. (2021). Similar to their findings, the participants learnt and expanded their meaning-making capabilities (Daniels, 2002) and became accountable for their learning when they needed to find and share the literary devices through the online literature circles.

The role of the Discussion Director was equally perceived as interesting, and they loved it. The participants discussed topics and questions that they were concerned and interested in. This builds motivation in learning literature, as the engagement in social interactions about literature gave them space and time to share, listen to, think, and reflect from multiple perspectives about literature. This was in line with findings from previous studies conducted by Dogan et al. (2020), $\mathrm{Li}$ (2018), and Noah (2018). The experience of learning together also created a valuable platform for practice, training, and development of communication and critical thinking skills, which contributed to cognitive and language development apart from quality attributes such as cooperation and team spirit.

The Imaginative Illustrator's role challenged the participants to move beyond the efferent stance. In reading and exploring meaning, the role nurtures exploration into the aesthetic, triggering imagination and creativity (Karolides, 2020). The illustration exhibited hidden talents and encouraged other participants also to adopt the aesthetic stance when they expressed 
personal feelings and thoughts from multiple perspectives about the picture. The aesthetic stance can be nurtured when meaning is explored personally and shared through social interactions (Rosenblatt, 1978; Daniels, 2002) and the assigned role has the power to assist the participants to embrace aesthetic and cognitive skills $(\mathrm{Li}, 2018)$.

Next, the role of the Passage Picker was perceived as the second most interesting role. This is parallel to the discovery by Cave (2018) who found that literature circles nurture deep aesthetic and thinking processes through reflective practice. The participants were not only engaged during the discussion, but they also became critical in responding to their groupmates.

Alternatively, the findings for the second research question on challenges as depicted in Figure one and Table three proved that the participants did not face a lot of challenges. The two main challenges were the language in the play and the roles in literature circles. For the language presented in Hamlet, Murphy et al. (2020), explained that different syntax order may have challenged learners in reading the play. As for the second challenge, the findings showed that the Imaginative Illustrator's role was perceived as the most challenging. In adopting this role, Karolides (2020) justified that participants had to move beyond the efferent stance into the aesthetic, triggering imagination and creativity. The illustration in Figure 3 exhibited hidden talents and encouraged other participants also to adopt the aesthetic stance when they expressed personal feelings and thoughts from multiple perspectives about the picture. This is similar to the finding in a study by Li (2018) who found the roles in literature circles to have the power to develop the aesthetic skills. The role was also successful in promoting different skills and knowledge through the picture and the use of technology (Combes, 2021). This was also consistent with the findings of the study by Ferdiansyah et al. (2020). The role of the Imaginative Illustrator may have challenged the participants to explore the aesthetic stance. However, it also nurtured their ability to develop and share meaning through social interactions.

With regards to the third research question, the findings showed that the participants addressed the challenges on the language and roles by doing more reading. Others were resourceful in getting help from the 'experts' in the online literature circles, which according to Çetinkaya and Topçam (2019), demonstrated cooperation and teamwork in advancing different skills and attributes. The experience motivated them to become innovative in finding solutions. According to Dogan et al. (2020) and Ardi (2017), resolving challenges faced nurtures learning autonomy among learners.

For quality online discussions, it depends not only on smooth planning on the part of the instructor (Varga et al., 2020) and the active participation of learners (Cave, 2018), but also on technology (Combes, 2021) as it influences the quality of learning for both the participant who faced internet problem and other members during the online literature circles. The online literature circles created a conducive environment for literature instruction among the TESL preservice teachers. Through the different roles, this study revealed the advancement of different skills and attributes that ensure quality in preparing these trainees to become active literature learners and talented future TESL teachers (Aytan, 2018). 


\section{Conclusion}

This article uncovered the perceptions of TESL pre-service teachers on the use of online literature circles as the instructional means for the learning of Hamlet. The findings showed that the participants' perceptions were positive, and found learning literature through online literature circles as interesting, engaging, challenging, fun, and they loved it. Though some faced challenges related to the language of Shakespeare's play, the roles for the online literature circles, internet connection, time management, or lack of technology skills, online literature circles were effective as a platform to train TESL pre-service teachers for literature instruction. The experience was vital in nurturing different learning abilities and attributes like cognitive, affective, and language skills and significant qualities such as cooperation, team spirit, ability to view multiple perspectives, hidden talents, motivation, and aesthetic pleasure.

In preparing a training ground for TESL pre-service teachers, literature instruction should include online literature circles. During the training, different skills involving language, cognitive, affective, and professional attributes can be nurtured. The nurturing of these skills and attributes builds the pre-service teachers' social, ethics, and passion towards the teaching profession.

Acknowledgments: The research is funded by Universiti Teknologi Malaysia under a research grant no. Q.J130000.2653.18J28 PY/2019/01727.

\section{About the Authors:}

Dr. Tina Abdullah is a senior lecturer at Universiti Teknologi Malaysia with 28 years of teaching experience. Actively involved as a teacher trainer, her areas of interests are in Literature in ELT, Meaning Making, and Materials Development. ORCID ID: 0000-0003-4551-6580

Dr. Yee Bee Choo has more than 20 years of teaching experience. She is a lecturer at Institute of Teacher Education Tun Hussein Onn Campus, Malaysia. Yee obtained her Ph.D. in TESL. Her research interest is in ELT, teacher education, and literature. ORCID ID: 0000-0001-7169-1396

Dr. Norhanim Abdul Samat is a teacher trainer attached to Universiti Teknologi Malaysia with a PhD in Process Drama. Her areas of expertise are Applied Literature in ELT, Process Drama, Drama Education, Communication and Language Arts. ORCID ID: 0000-0003-0110-5798

\section{References}

Alamoudi, K. A. (2021). Interventions to improve a practicum course for EFL Teachers in Saudi. Arab World English Journal, 12(12), 59-70. DOI:

https://dx.doi.org/10.24093/awej/vol12no1.5

Alexander, R. (2018). Developing dialogic teaching: Genesis, process, trial. Research Papers in Education, 33(5), 561-598. DOI: https://doi.org/10.1080/02671522.2018.1481140

Ardi, P. (2017). Promoting Learner Autonomy through Schoology M-Learning Platform in an EAP Class at an Indonesian university. Teaching English with Technology, 17(2), 55-76.

Aytan, T. (2018). Perceptions of prospective Turkish Teachers regarding Literature Circles. International Journal of Educational Methodology, 4(2), 53-60. 
Arab World English Journal (AWEJ) Volume 12. Number 4. December 2021

Online Literature Circles in Learning Hamlet among Pre-service Teacher

Abdullah, Yee \& Abdul Samat

Bales, J. (2021, March). Literature circles in a synchronous virtual classroom: Educational MOOs to support student online interaction. In IASL Annual Conference Proceedings (pp. 17-35). DOI: https://doi.org/10.29173/ias18096

Beach, R., \& O’Brien, D. (2017). Significant Literary Research informing English Language Arts instruction. In D. Lapp, \& D. Fisher (Eds.), Handbook of Research on Teaching the English Language Arts. (pp. 1-26). New York: Routledge.

Bloemert, J., Paran, A., Jansen, E., \& Grift, W. (2019). Students' perspective on the benefits of EFL Literature Education. The Language Learning Journal, 47(3), 371-384. DOI: https://doi.org/10.1080/09571736.2017.1298149

Cave, C. (2018). Benefits of Online Literature Circles in the college arena. The Journal of Global Business Management, 14(2), 47-56. Retrieved from http://www.jgbm.org/page/6\%20Chessica\%20Cave.pdf

Çetinkaya, F. Ç., \& Topçam, A. B. (2019). A different analysis with the Literature Circles: Teacher Candidates' perspectives on the profession. International Journal of Education and Literacy Studies, 7(4), 8-16. Retrieved from https://eric.ed.gov/?id=EJ1234296

Combes, B. (2021, March). Literature Circles Online: Practical strategies for creating a reading culture using technology. In IASL Annual Conference Proceedings (pp. 293-301). Retrieved from https://journals.library.ualberta.ca/slw/index.php/iasl/article/view/8061

Daniels, H. (2002). Literature circles: Voice and Choice in Book Clubs and Reading Groups. ( $2^{\text {nd }}$ ed.) Portland, ME: Stenhouse.

Dhawan, S. (2020). Online learning: A Panacea in the time of COVID-19 Crisis. Journal of Educational Technology System, 49(1), 5-22. DOI: https://doi.org/10.1177\%2F0047239520934018

Dogan, B., Yildirim, K., Cermik, H., \& Ates, S. (2020). Promoting Pre-Service Teachers' reading attitudes through Literature Circles: A Mixed Methods design. International Journal of Educational Methodology, 6(4), 653-667. DOI: https://doi.org/10.12973/ijem.6.4.653

Ferdiansyah, S., Ridho, M.A., Sembilan, F.D., \& Zahro, S.F. (2020). Online Literature Circles during the COVID-19 Pandemic: Engaging undergraduate students in Indonesia. TESOL Journal, 11(3/e544). DOI: https://doi.org/10.1002/tesj.544

Fortune, D., Horst, P., Kessler, M. A., Tackett, M. E., \& Pennington, L. K. (2021). Using Virtual Book Clubs to elevate discussion and diverse voices. In Handbook of Research on Teaching Diverse Youth Literature to Pre-Service Professionals (pp. 318-338). IGI Global.

Greef, E., Jenkins, Y., \& Comer, A. (2021, March). The power and the passion: Igniting a love of reading through Literature Circles. In IASL Annual Conference Proceedings (pp. 311320).

Imamyartha, D., Wahjuningsih, E., Puspa, A., Fitriyah, S. M., Hudori, R. F. A., Andayani, R., Tasnim, Z., Fardhani, A. E. \& Wijaputra, B. A. (2021). Employing Blended Literature Circles to foster activating academic emotions of Struggling Readers.| IRJE| Indonesian Research Journal in Education|, 5(1), 293-310. DOI: https://doi.org/10.22437/irje.v5i1.9855

Joni, D. A. A. W. (2019). Initiation-Response-Evaluation (IRE) technique collaborated with panel discussion activity in teaching speaking skill. Jurnal Santiaji Pendidikan (JSP), 9(1), 88-94. DOI: https://doi.org/10.36733/jsp.v9i1.187

Karolides, N.J. (2020). Reader Response in Elementary Classrooms. New York: Routledge. 
Arab World English Journal (AWEJ) Volume 12. Number 4. December 2021

Online Literature Circles in Learning Hamlet among Pre-service Teacher

Abdullah, Yee \& Abdul Samat

Kaşlığlu, Ö., \& Ersin, P. (2018). Pre-service Teachers' beliefs about Literature integration in English Language Teaching classrooms. Journal of Language and Linguistic Studies, 14(3), 213-232. Retrieved from https://eric.ed.gov/?id=EJ1193276

Li, P. (2018). Impact of Virtual Literature Circles on Chinese University EFL Students' Independent English Reading. Doctoral Thesis, Michigan: Oakland University.

Li, Y., Chen, K., Su, Y., \& Yue, X. (2021). Do social regulation strategies predict learning engagement and learning outcomes? A study of English language learners in wikisupported literature circles activities. Educational Technology Research and Development, 69(2), 917-943. Retrieved from https://link.springer.com/article/10.1007/s11423-020-09934-7

Masry, T.E., \& Alzaanin, E.I. (2021). Uncovering new paths to adaptation: A Case Study of Malaysian English as a Second Language Pre-service Teachers. Arab World English Journal, 112(1.28). 421-442. DOI: http://dx.doi.org/10.2139/ssrn.3826857

Moorhouse, B.L. (2020) Adaptations to a Face-To-Face Initial Teacher Education course 'Forced' Online due to the COVID-19 Pandemic. Journal of Education for Teaching, 46(4), 609-611, DOI: https://doi.org/10.1080/02607476.2020.1755205

Murphy, S., Culpeper, J., \& Gillings, M. (2020). What do students find difficult when they read Shakespeare? Problems and solutions. Language and Literature, 29(3), 302-326. DOI: http://dx.doi.org/10.1177/0963947020949441

Noah, J.B. (2018). Cultivating responses from students through Literature Circle. International Journal of Research in English Education, 3(1), 1-10.

Nor Pazilah, F., Hashim, H., \& Md Yunus, M. (2021). Service-learning in English as a Second Language Teacher Training Program: Exploring Pre-service Teachers' authentic learning experiences. Arab World English Journal. 12(2), 377-398. DOI:

https://dx.doi.org/10.24093/awej/vol12no2.26

Novitasari, Rahayu, E. K., Suryanto, B. (2021). Literature Circles in Reading Class: Students' participation and perception. Celtic: A Journal of Culture, English Language Teaching, Literature, \& Linguistics, 8(1), 65-77. DOI: https://doi.org/10.22219/celtic.v8i1.16138

Nurhadi, K. (2017). The Effectiveness of Initiation Response Evaluation strategy in Teaching students' Reading Comprehension. Journal of English Language Learning, 1(1), 48-56. Retrieved from https://media.neliti.com/media/publications/318841-the-effectiveness-ofinitiation-response-126cc2c8.pdf

Rosenblatt, L.M. (1978). The Reader, the Text, the Poem: The Transactional theory Of the Literary Work. Illinois: Southern Illinois University Press.

Sefhedi, S. T., Omidire, M. F., Ebersöhn, L., \& Murphy, P. K. (2020). Promoting CriticalAnalytic Thinking through Teacher Discourse Moves and Pedagogical Principles: The case of a rural South African secondary school. Journal for Language Teaching, 54(2), 95-117. DOI: https://doi.org/10.4314/jlt.v54i2.5

Varga, Z., McGuinn, N., Naylor, A., Rimmereide, H.E., \& Syed, G. K. (2020). We are invited to imagine: Using a literary text to encourage cross-cultural dialogue about citizenship. Cambridge Journal of Education, 50(4), 501-519. DOI: https://doi.org/10.1080/0305764X.2020.1736002

Vygotsky, L. (1978). Interaction between learning and development. Readings on the Development of Children, 23(3), 34-41. Retrieved from https://innovation.umn.edu/igdi/wpcontent/uploads/sites/37/2018/08/Interaction_Between_Learning_and_Development.pdf 